\title{
SoTL Inquiry in Broader Curricular and Institutional Contexts: Theoretical Underpinnings and Emerging Trends
}

\section{ABSTRACT}

Universities around the world increasingly recognize the importance of offering high quality, high-engagement student learning experiences in their undergraduate and graduate programs. While the SoTL movement and literature has gained considerable recognition and momentum over the past two decades, much less inquiry has focused on institutional and program-level educational reforms. This paper calls for a more expansive view and strategic use of SoTL inquiry in order to make substantive contributions to curriculum renewal, educational leadership practices, and, most importantly, the quality of undergraduate and graduate degree programs. Theoretical underpinnings, emerging trends, challenges, and strategic supports to enhance the effectiveness and efficiency of curricula within and across diverse disciplinary contexts are discussed.

\section{KEYWORDS}

higher education, scholarship of teaching and learning, inquiry into curriculum practice, educational leadership, institutional supports

\section{INTRODUCTION}

The Scholarship of Teaching and Learning (SoTL) has made great strides over the past two decades to contribute both to enhancing the quality of teaching and learning in higher education and the growing body of educational research. The field has moved well beyond Boyer's original conception and continues to evolve, with calls now being seen for greater attention to theoretical and methodological rigour (Boyer, 1990; Glassick, Huber, \& Maeroff, 1997; Hubball \& Clarke, 2010; Hutchings, Huber, \& Ciccone, 2011; Kanuka, 2011; Svinicki, 2012). Given this increasing maturation of the field and the significant educational reforms currently taking place in research-intensive universities around the world, this article argues for a more expansive view and strategic use of SoTL inquiry in order to have a much greater impact on the quality of curriculum and pedagogical practices within and across diverse disciplinary contexts (Hubball, Clarke, \& Poole, 2010; Hubball, Lamberson, \& Kindler, 2012). SoTL inquiry has the potential to make substantive contributions to institutional-level educational reforms, curriculum renewal, educational leadership practices, and, most importantly, the quality of undergraduate and 
graduate degree programs. The authors' insights are grounded in scholarship, curriculum leadership, and collaboration experiences at the University of British Columbia (UBC) and with colleagues from institutions in many parts of the world, and in the experience of supervising SoTL leadership development of over 300 cross-disciplinary faculty members from Canadian and international universities.

\section{The Case for a More Expansive View of SoTL to Enhance Curriculum Practices}

While the SoTL movement and literature have gained considerable recognition and momentum over the past two decades, the emphasis has primarily been on individual pedagogical practices in the classroom. Much less inquiry has focused on program-level educational reforms that are occurring in universities around the world. Despite prominent calls by senior administrators and educational leaders for more institutional research in this area, this surprisingly languishes as an area of scholarship. Traditional undergraduate and graduate degree programs, for example, often consist of an ad hoc mix of individual course-based and modular experiences and limited assessments of learning (e.g., through over-reliance on written midterm and final examinations), with neither strategic alignment nor integration with program-level learning experiences and outcomes (Bresciani, 2006). Further, these programs frequently lack the theoretical underpinnings and systematic and scholarly inquiry (e.g., evaluation of organizational structures, curriculum development and implementation processes, and immediate and long-term outcomes) that would allow for evidence-based decision-making to enhance the effectiveness and efficiency of curricula (Green, 2008; Hubball \& Pearson, 2011; Shulman, 1986).

The educational landscapes at research-intensive universities are complex and rapidly changing, with increases in disciplinary specialization, student diversity, proliferation of course and program options, and use of technology to expand classroom borders occurring simultaneously with increasingly vocal calls for institutional accountability. In such an environment, inquiry into curriculum practice not only extends the existing literature in the SoTL field; it also takes curricula and institutions to a higher level of excellence. Moreover, this is consistent with the research ethos and methodological rigor espoused by research-intensive universities; it is more likely to be accepted by senior administrators and educational leaders and to meet the diverse needs and circumstances of these institutions (Arai et al., 2007; Bass, 2012; Bates \& Sangrà, 2011; Elen, Lindblom-Ylänne, \& Clement, 2007). The demonstrable use and maturity of SoTL as a field of inquiry-based practice is aligned with the urgent need for senior administrators and educational leaders to make evidence-based decisions for institutional-level and program-level educational reforms (Green, 2012). Therefore, we argue that the time has come for a more expansive view and strategic use of SoTL in order to enhance the effectiveness and efficiency of curricula within and across diverse disciplinary contexts. ${ }^{1}$

\section{Inquiry into Curriculum Practice: What's Old is New Again!}

At the outset, we wish to argue that inquiry into curriculum practice is as old as educational programming itself. However, for too long (and especially in recent times) systematic and scholarly inquiry into curriculum practice has not been prioritized or enacted within academe. A brief history of inquiry into curriculum practice and the politics at play with respect to the generation of its knowledge illustrates this point (see Figure 1). 
For example, there are at least four distinct trends in the generation of knowledge about curriculum practice since the 1950s to present. Each trend had a particular impact on the ways in which inquiry into curriculum practice has been conceptualized and enacted within higher education (Collins \& Clarke, 2008).

Figure 1: Trends in inquiry into curriculum practice that have influenced what 'counts' as knowledge.

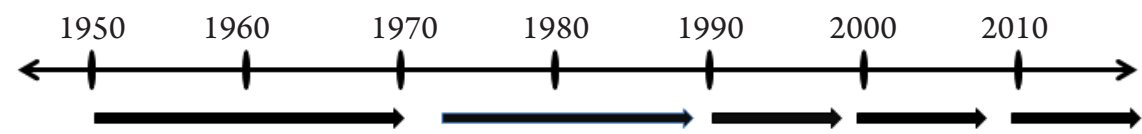

$\begin{array}{lllll}\text { Inquiry of } & \text { Emergence of } & \text { Mixed method } & \text { Situated nature of } & \text { Diverse inquiry } \\ \text { a primarily } & \text { qualitative inquiry } & \text { forms of inquiry } & \text { inquiry, includ- } & \text { methods, including } \\ \text { experimental/ } & \text { methods, for } & \text { and more inclusive } & \text { ing self-study and } & \text { emerging } \\ \text { quantitative nature, } & \text { example case } & \text { epistemologies } & \text { action research } & \text { curriculum } \\ \text { for example, linear } & \text { studies } & & & \text { analytics }\end{array}$

The first distinct trend gained momentum with events such as the launch of Sputnik in 1957 that focused widespread political, economic, and public attention on the virtue of educational programs. Curricula were typically framed by linear causal models, beginning with easily-measurable aims and objectives, followed by a series of progressively challenging learning activities, and ending with assessment and evaluation of discrete behavioural outcome variables (Taba, 1962; Tyler, 1949). Inquiry into curriculum practice during this period was dominated by quantitative research methods such as experimental and quasi-experimental studies that controlled for bias and were intended to yield scientific generalizations about curriculum practices (Campbell \& Stanley, 1963; Dressel, 1968; Scriven, 1967). However, these important foundational methods tended to produce limited data and equivocal findings for improving curriculum processes.

During the 1970s and 1980s, much greater appreciation was given to the role of context in the design and implementation of educational programs (Ottoson \& Green, 1987; Stake, 1975; Weiss, 1973). There was recognition that theory-driven curricular designs were subject to adaptation, with consequences for the intended behavioural and non-behavioural outcomes. This occurs because curricular implementation depends on factors such as the knowledge, skills, and attitudes people bring to it and the resources at hand, so curriculum practice can vary considerably with local situations and changing circumstances. Inquiry into curriculum practice during this period began to embrace new methodologies in order to adequately address these insights. Notably, qualitative research methods, such as case study research, became increasingly recognized and valued as legitimate and useful forms of inquiry into curriculum practice (Conrad \& Pratt, 1983; Green, 1986; Tierney, 1989).

The 1990s saw the development of mass higher education to serve a rapidly changing student body, increasingly diverse in age, gender, sexual orientation, culture, ethnicity, and social class. At the same time, alarm was growing about the profound social, political, economic, and environmental problems of the world students would be entering. Curricula thus began to be driven by institutional and societal expectations that students would be 
educated as technologically adept lifelong learners and global citizens, with attributes including the ability to think critically and solve problems, to collaborate, communicate, and lead effectively, and to act in an ethically and socially responsible manner. These general learning outcomes tended to cut across most disciplines, but were particularly prominent in professional programs, which emphasized competency-based outcomes. By the turn of the millennium, technical rational approaches to inquiry into curriculum practice had given way to more diverse and inclusive epistemologies. Such inquiry was increasingly viewed as a social construction and therefore engaged students, faculty, administrators, and other stakeholders (Baxter Magolda, 1999; Diamond, 1998; Green \& Kreuter, 1991; Haworth \& Conrad, 1997).

From 2000 to 2010, coinciding with developments in the field of SoTL, generative concepts emerged encompassing more situated and complex sociocultural influences on intended (and unintended) processes and outcomes of curriculum practice (Fullan, 2001; Hansman, 2001; Hubball \& Burt, 2004; Lave \& Wenger, 1991). In order to authentically support and engage the lived experience of curriculum stakeholders, this period saw a greater use of inquiry methods that were previously largely ignored or unknown in educational research (e.g., action research, autobiography, and self-study research). During this time, in addition to accreditation and other obligatory external reviews of academic programs, inquiries into curriculum practice largely focused on learning-centred course design, student engagement, and outcomes-based assessment, and much less on program-level curriculum renewal initiatives or any substantive consideration of a theoretical basis for curriculum practice in diverse undergraduate and graduate program contexts (Christensen-Hughes, 2007; National Survey of Student Engagement, 2005). In 2007, with an explicit transformational agenda at the local level in higher education, the term "Scholarship of Curriculum Practice" (SoCP) was introduced as a distinct but complementary and necessary area of research within SoTL (Hubball \& Gold, 2007). Parallel with the SoTL literature, an important distinction is made between scholarly approaches to curriculum practice and the Scholarship of Curriculum Practice (SoCP). Scholarly approaches to curriculum practice can engage faculty at all ranks in reflecting upon, debating, and initiating positive changes to curricula. The SoCP takes scholarly approaches to curriculum practice to another level of methodological rigour and includes an expectation for peer review and public dissemination of curriculum inquiries (Hubball, Gold, Mighty, \& Britnell, 2007; Richlin \& Cox, 2004).

Presently, in an environment of rapid technological change, limited and competing resources, and unprecedented diversity in the student body in higher education, curricula within and across disciplinary contexts are being scrutinized as never before. The turn to SoCP thus provides a scholarly foundation for strategic and systematic approaches to curriculum renewal, as well as for addressing key issues of effectiveness and efficiency of curriculum practices. Although there are significant overlaps in the constructs of curriculum effectiveness and efficiency, our research and professional experience with curriculum communities in various settings suggests that constructs of curriculum effectiveness include state-of-the-art, cutting-edge, coherent, and integrated learning experiences; demonstrable high-level learning outcomes; influence and profile of the program and its graduates in society; satisfaction levels of stakeholders; and quality of curriculum leadership and professional development supports. Meanwhile, constructs of curriculum efficiency might include strategic alignment of curriculum learning experiences with in- 
tended outcomes; maximal use of available budget and other resources to enhance student learning; optimal instructor/coordinator/leadership-to-costs ratio; strategic use of learning technologies; and sustainability, including the ability to attract high quality students and minimize attrition.

Building on the full range of methodological approaches to address issues of curriculum effectiveness and efficiency, emerging technology-enabled inquiry methods have enormous potential for SoCP contributions. For example, curriculum analyticsthe integrated use of data, research methods (qualitative and quantitative analysis), and technology-is moving centre-stage for curriculum leaders and its stakeholders (Wagner \& Ice, 2012). Through the use of technology, curriculum analytics captures the complex, situated, and dynamic nature of curriculum practice. It affords relatively easy and thorough mining of practice-based evidence in order to drive effective decision-making to enhance curriculum organizational structures, curriculum development, curriculum implementation, and curriculum evaluation processes. With a focus on student learning, curriculum analytical cultures are fundamentally curious about improvements and marked by collaboration and information sharing across disciplinary and institutional boundaries (Bryk, Gomez, \& Grunow, 2011). In this context, therefore, SoCP internalizes theory and practice through a systematic, rigorous, and cyclical process of inquiry. Thus, SoCP is shaped by diverse learning contexts and focuses on practice-driven inquiries with particular epistemological (i.e., how we know what we know), methodological (i.e., approaches to research design, data collection, and analysis), and ethical (i.e., informed consent) considerations (LaBoskey, 2004). SoCP situates knowledge construction as ontologically complex and draws upon diverse theoretical, disciplinary, and methodological frameworks. It also acknowledges the multiple societal, institutional, professional, disciplinary, and pedagogical perspectives, methods, and priorities of its key stakeholders.

\section{THEORETICAL UNDERPINNINGS AND CONCEPTUAL FRAMEWORK FOR SOCP}

\section{Theoretical Perspectives}

Grounded in the social sciences and drawing on new technologies and diverse methodologies, SoCP is represented in the higher education literature from multiple perspectives (e.g., theories of organizational change, educational programs, curriculum, and pedagogy). No single theory is adequate to tie together the multiple levels of influence on curriculum practice (Hutchings, 2007; Pinar, 2012). However, combining theories is not completely satisfactory since there are not agreed guidelines for selecting individual or combinations of theories. Thus, oriented by the literature and contemporary approaches to curriculum and pedagogical practices in higher education, we believe that there are at least three interrelated assumptions about SoCP that are significant. These assumptions are intimately related and are regularly the subject of debate within the higher education research community. All three assumptions play a part in the way we make sense of SoCP. Specifically, we suggest that SoCP is 1) inherently situated, 2) socially mediated, and 3) locally implemented (Hansman, 2001; Hubball \& Burt, 2007; Hubball \& Gold, 2007; McKinney, 2012; Richlin \& Cox, 2004; Senge \& Scharmer, 2008). For example, the principle that SoCP is inherently situated within disciplinary traditions, learning environments, and historical and political landscapes is part of the 'signature pedagogies' 
within which faculty are practicing and, therefore, frames what is acceptable in terms of curriculum initiatives (Lave \& Wenger, 1991; Shulman, 2005). This principle is also seen in the strategic recruitment of recognized leaders within academe (e.g., administrators, senior faculty, and students) and the field (e.g., practicing professionals) to curriculum leadership teams mandated to engage key stakeholders and to identify discipline-specific curriculum development goals. Thus, this dimension acknowledges the art, science, and politics of SoCP (Westerheijden, Stensaker, \& Rosa, 2007).

The socially mediated aspect of SoCP speaks to the notion of communities of practice, in particular the complex institutional, disciplinary, and curriculum contexts (social, political, economic, organizational, and cultural) in which SoCP take place (Beaudoin, 2012; Cousin, 2009; Friedman, 2008). SoCP in a research-intensive university setting can involve faculty members at various institutional levels. For example, academic units are increasingly using technology to facilitate internal sharing and utilization of curriculum data. This sort of engagement of key stakeholders (e.g., administrators, academic peers, and students) in opportunities for discourse, learning analytics, and leadership around curriculum initiatives goes a long way to developing curriculum communities and enhancing the validity, reliability, and practicality of SoCP (Bryk et al., 2011; Wenger, McDermott, \& Snyder, 2002).

The third assumption recognizes that within and across diverse disciplinary contexts, it is curriculum leaders and key stakeholders who generate knowledge from inquiries into curriculum practice. For example, a community of SoCP practitioners determines which SoCP research questions or outcome indicators to examine, which literature sources and theoretical frameworks will inform SoCP research and practice in their particular setting, what data to gather, when and how to collect and analyze these data, how to initiate positive changes to enhance curriculum practice, how to engage key stakeholders in ongoing collaborative projects, and, finally, to consider how SoCP research might be of interest to and disseminated in the broader scholarly community (Ambrose et al., 2010; Cochran-Smith \& Lytle, 2004; Hubball \& Pearson, 2010; Kurtz \& Sponder, 2010). Acknowledgement of the underlying assumptions and theoretical underpinnings and a conceptual framework are key foundations for enhancing strategic and scholarly approaches to curriculum practices.

\section{Conceptual Framework for Conducting SoCP Inquiry}

We argue that there is no one single strategy to conduct SoCP inquiry in a university setting. The flexible and iterative framework illustrated in Figure 2 has been employed within and across diverse disciplinary and institutional contexts (Hubball \& Burt, 2007; Hubball \& Clarke, 2010; Hubball \& Edwards-Henry, 2011; Hubball, Gold, Mighty, \& Britnell, 2007; Hubball \& Pearson, 2011). Essentially, this SoCP framework enables diverse theoretical, disciplinary, and methodological approaches to enhance the effectiveness and efficiency of curriculum practices within and across diverse disciplinary contexts.

SoCP context inquiry. These investigations delve into the relevant SoCP literature and the 'big picture' factors (e.g., situated institutional, disciplinary, and unit-specific strategic plans, political structures, and resources) that shape curriculum practices in universities (Cochran-Smith \& Lytle, 2004). In practical terms, this includes appropriate consultation, collaboration, and attention to relevant supporting literature and best practices in the field, as well as maximizing available resources, supports, and incentives 


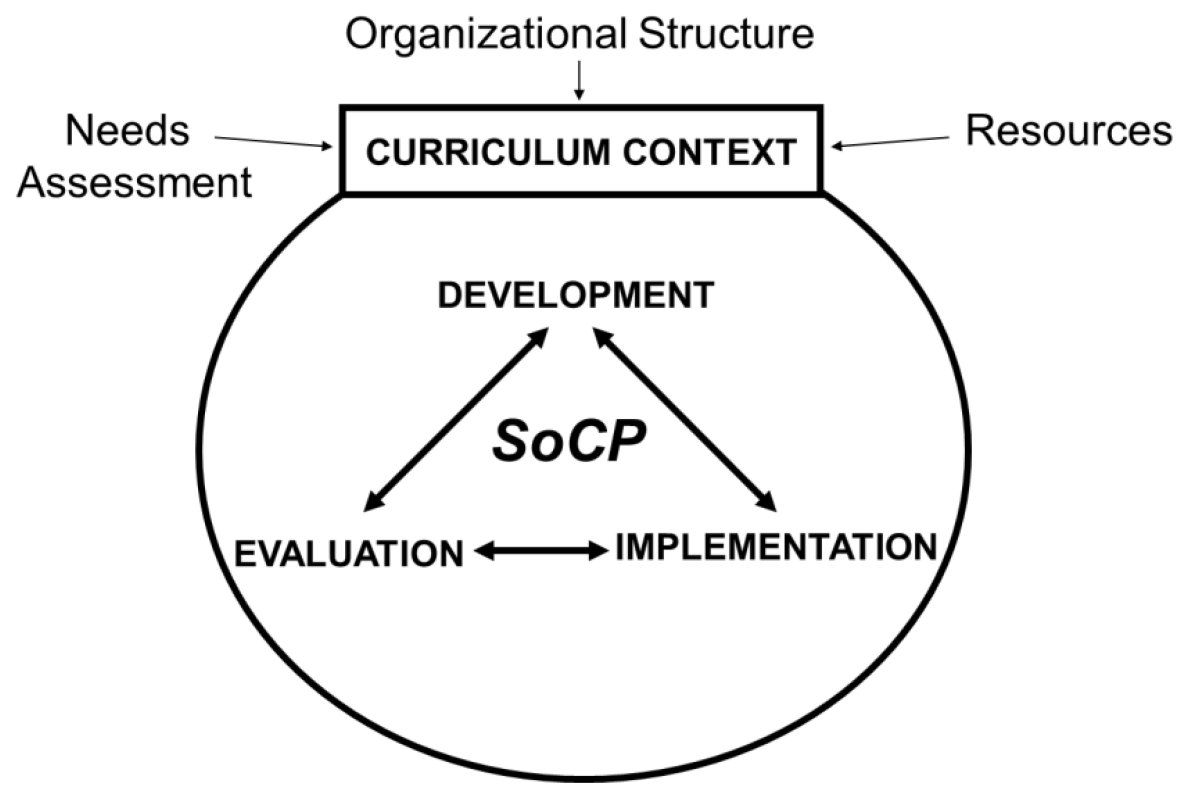

Figure 2. Conceptual framework for conducting $\mathrm{SoCP}$ in a research-intensive university

to meet diverse needs and circumstances. Thus, these investigations ensure that SoCP is not only meaningful and relevant, but is also manageable to administer, and, above all, empowers the curriculum community to engage in scholarly approaches to curriculum practices. Curriculum context inquiries might seek to identify current educational offerings and goals for further development, innovations and challenges, and/or the further supports required to enhance scholarly approaches to curriculum renewal. Relevant questions include what is the current status of faculty-wide curriculum practices? What are the available institutional and external resources to facilitate curriculum renewal? What needs to be improved, why, and how?

SoCP development inquiry. These investigations take into account all components of the conceptual framework for SoCP (i.e., context, implementation, and evaluation) and include the examination and planning of program-level learning outcomes, pedagogical strategies, and sequencing and integration of learning experiences and assessment opportunities, all of which drive curriculum practices (Pearson \& Hubball, in press). For example, one might ask what are the challenges when developing program-level learning outcomes? What sorts of program-level learning outcomes are suitable for this setting? Who should contribute to the articulation of program-level learning outcomes and assessment strategies? How are student learning experiences integrated in this setting? What pedagogical strategies and curricular structures are needed to support students' achievement of program-level learning outcomes? What needs to be improved, why, and how?

SoCP implementation inquiry. These investigations take into account the strategic and integrated pedagogic experiences throughout a multi-year curriculum, which might include substantive student research and capstone experiences; international, aboriginal, and community-service engagement initiatives; and distance learning provision. Inquiry here might focus on a detailed examination of the quality of teaching and student learn- 
ing experiences (Chickering \& Gamson, 1987; Chism, 2007), and ask to what extent are learning outcomes made explicit to students through course syllabi? To what extent are effective teaching and student engagement practices employed? How do students demonstrate learning outcomes? What are the strengths and weaknesses of curriculum learning experiences? What needs to be improved, why, and how?

SoCP evaluation inquiry. These investigations refer to the deliberate planning of data collection and analysis (e.g., the triangulation of data from curriculum documents, focus groups, and students' work) in order to enhance the effectiveness and efficiency of curriculum practices. Indicators for curriculum effectiveness and efficiency will vary enormously depending on contextual factors, although ultimately should be defined and employed (in the same way as program-level learning outcomes) by the respective curriculum community, including key stakeholders. Of importance here is attention to intended audience, resources, objectives of the particular SoCP inquiry, research questions and outcome indicators, research design and standards, and the inseparable relationship between formative and summative evaluation (Saunders, Trowler, \& Bamber, 2011). Possible questions include to what extent are graduates situated in leadership and/or employment positions within the community? Generally speaking, to whom and to what extent did the curriculum make any difference? How, if at all, did the curriculum contribute to students' development as citizens in a diverse world? How does this program compare with others in similar contexts? To what extent are program resources efficiently deployed? What needs to be improved, why, and how?

As these examples illustrate, this inclusive SoCP framework provides a scholarly foundation for strategic and systematic approaches to SoCP in diverse disciplinary contexts. Specifically, it invites curriculum leaders to identify relevant SoCP objectives and appropriate methodologies in order to obtain findings (in the short-term, intermediate and long-term) that can be used to enhance the effectiveness and efficiency of curriculum practices. In practice, this serves to improve organizational structures, communication, and interactions with key stakeholder groups, and to enhance curriculum development and implementation processes such as strategic alignment of overall program-level learning outcomes, course pedagogies, and assessment of graduate attributes.

\section{SOCP DEVELOPMENTS AND ONGOING CHALLENGES: A CAUSE FOR OPTIMISM AND CAUTION}

SoCP is still very much in its infancy, both theoretically and practically, and much more needs to be done to enhance the strategic use, visibility, and support of such inquiry. Nevertheless, there are encouraging signs of progress in universities around the world. We are beginning to see more collaborations, expertise, leadership, and scholarship in this field; significant restructuring of universities to address educational reforms; and emerging SoCP support initiatives.

\section{Institutional restructuring to support curriculum renewal}

Universities around the world are busily engaged, with mixed success, in curriculum renewal and educational reform activities. Many universities undergoing significant reforms have developed mission statements with explicit commitments to innovative curricula and pedagogy informed by contemporary research on how people learn. Furthermore, institutional centres for teaching and learning are being restructured to work more 
closely with senior administrators and to anchor their activities in the needs of academic units for evidence-based approaches to curriculum and pedagogy (Clark \& Saulnier, 2010; Holt, Palmer, \& Challis, 2011). Both centralized and faculty-specific support units and development programs are increasingly rooted in the Scholarship of Teaching and Learning (SoTL), whereby inquiry informs educational practices and the scope of supports includes those that are technology-enabled (Marshall, Orrell, Cameron, Bosanquet, \& Thomas, 2011). In conjunction (although not always at the same pace or ideally synchronized), some universities are reconsidering criteria for merit, tenure, and promotion in light of commitments to curriculum renewal and educational reform activities.

As an example, our own university's Institute for the Scholarship of Teaching and Learning has been restructured, aided by part-time faculty secondments strategically funded by the Office of the Provost. This has brought together a small group of recognized curriculum leaders and scholars (and collaboration with the university's new Strategic Decision Support Group, which offers cost and efficiency analysis of alternative educational solutions) with expertise to support strategic, effective, and efficient SoCP initiatives in multidisciplinary settings. The curriculum leadership team has focused on facilitating scholarly approaches to curriculum renewal within and across the disciplines, at both undergraduate and graduate levels (see http://ctlt.ubc.ca/about-isotl/programs-events / curriculum-consulting-and-scholarship/). This undertaking began with an institutionwide environmental scan of curriculum practices to identify current offerings and goals for further development, innovations and challenges, as well as further supports needed to enhance scholarly approaches to curriculum renewal in the Faculties of Arts, Applied Sciences, Dentistry, Education, Land and Food Systems, Medicine, Law, Pharmaceutical Sciences, and Science, the Sauder School of Business, and the College of Health Disciplines. This was followed by a series of institution-wide curricula forums for showcasing curriculum innovations (including those supported through the Carl Wieman Science Education Initiative); identifying key challenges and similarities and the diversity of learning-centred educational practices (e.g., program-level learning outcomes assessment; enriched educational experiences including the first year experience, student research, and large classes; internationalization of curriculum, technology-enabled curriculum); and fostering a networked community to support SoCP (Wieman, Perkins, \& Gilbert, 2010; Wong \& Hubball, 2011). Each forum was opened by the Vice Provost and Associate Vice President Academic in order to reinforce the institutional visibility of and commitment to curriculum renewal initiatives. In particular, those faculties which had specific internal SoCP expertise, strategically hired faculty members with expertise in educational scholarship, and/or a relatively high proportion of UBC Faculty SoTL Leadership Program graduates, were best positioned to achieve success with SoCP (Hubball et al., 2012).

\section{SoCP support initiatives}

Obvious signs of change include the growth in curriculum-oriented special interest groups and conference programming within educational organizations such as the International Society for the Scholarship of Teaching and Learning (ISSOTL), and the increasing receptivity of journals and granting organizations to SoCP submissions. Of note was a recent invitational Universitas 21 Teaching and Learning Network Conference, attended by Provosts, Vice-Provosts, and other curriculum leaders from member institutions, that was dedicated to the sharing of experiences and exploration of research- 
informed and technology-enabled strategies to increase large-scale effectiveness and efficiency of curriculum practices intended to improve learning outcomes (University of British Columbia, 2011).

Many universities provide a wide range of curriculum enhancement initiatives that go beyond traditional faculty development seminars and workshop offerings. More than ever before, curriculum leaders are engaging in communities of practice and seeking specific mentoring assistance and collaborations that include 1) consultations with institutional units that specialize in cost and efficiency analyses of educational initiatives, and 2) new and exciting forms of educational scholarship and collaborations with colleagues in other disciplines (including Faculties of Education), institutions, and countries. We are also witnessing increasing numbers of graduate students, including tenured instructors seeking professional development, pursuing $\mathrm{MA}$ and $\mathrm{PhD}$ studies focused on SoCP in their discipline. At our university, for example, new forms of strategic inquiry and collaborations are evident through the UBC Faculty SoTL Leadership Program: Faculty Certificate on Teaching and Learning in Higher Education (see http://ctlt.ubc.ca/about-isotl /programs-events/faculty-sotl-program/). This flexible and technology-assisted cohort program has enabled over three hundred selected educational leaders to participate from UBC, Canadian, and international universities and has provided key foundational support for SoTL research methods and educational scholarship in diverse disciplinary contexts (Hubball, Clarke, \& Poole, 2010; Hubball \& Pearson, 2009). The strategic importance and support for developing this kind of local expertise in educational scholarship is demonstrated through the Deans' nominations for UBC participants, on up to the President, who awards graduation certificates at a prestigious annual ceremony.

\section{Challenges}

While there are encouraging signs of progress toward a more expansive view of SoTL in order to address urgent issues pertaining to program-level and institutional curricular reforms, myriad SoCP-related challenges remain on university campuses. For example, the term "SoTL" is sometimes narrowly interpreted as only applying to research on classroom and/or course-based pedagogical practices, rendering incredibly substantive contributions such as educational leadership, program-level reform, curriculum renewal initiatives, and related scholarship largely invisible in the recognized activity of a research-intensive university. Equally, competing institutional priorities (e.g., disciplinary research foci and criteria for merit, tenure, and promotion) may deem inquiry into curriculum practice as being insufficiently scholarly or important. Such attitudes, exacerbated by alreadysubstantial faculty workloads, often constrain efforts by curriculum leaders to systematically engage in SoCP inquiries.

We argue that without SoCP, undergraduate and graduate programs become perfunctory or routinized, duplicative, or imitative. When curriculum leaders and key stakeholders cease to systematically examine their curriculum practices, or the circumstances in which they work prevent or do not support such inquiries, then these curriculum practices will cease to be effective and/or scholarly. Even under supportive institutional conditions, however, it is far from easy for many faculty members to engage in SoCP. For example, institutional and program-level curricular reform is a complex, multifaceted, and iterative process. It is shaped by many factors (social, political, economic, organizational, cultural, and individual) and involves people at various institutional levels (e.g., 
administrators, curriculum development committee personnel, instructors, and learners) in complex university settings (Davis \& Sumara, 2006; Hubball \& Burt, 2004; Hubball \& Gold, 2007; Westerheijden et al., 2007). Not surprisingly, therefore, curricular reform poses significant research, as well as pedagogical and organizational, challenges for most institutions and academic units, administrators, and curriculum leaders. SoCP frequently requires faculty members to move beyond disciplinary research boundaries, embrace broader social science methodologies, and collaborate with students, colleagues, and key stakeholders in the field. Often, faculty members from disciplines unfamiliar with social science research methods lack appropriate methodological expertise and thus find it a significant challenge to conduct SoCP in complex institutional and program-level settings (Hubball \& Clarke, 2010).

Consequently, institutions and academic units need to engage in the strategic use and support of SoCP. This approach will not only enhance curriculum renewal; it is more likely to be accepted by senior administrators and educational leaders in order to address pressing issues around the effectiveness and efficiency of curriculum practices within and across diverse disciplinary contexts. However, caution is necessary to ensure a balance between the development goals and the quality control and efficiency agenda of SoCP, particularly given the typically greater resources available for the latter.

\section{CONCLUSIONS}

The role and impact of SoTL is increasingly the subject of scrutiny and debate on research-intensive campuses throughout the world. This article calls for a more expansive view of SoTL inquiry in order to have a much greater impact and enhance the effectiveness and efficiency of curriculum practices (e.g., organizational structures, curriculum development and implementation processes, and immediate and long-term outcomes) within and across diverse disciplinary contexts. This imperative is even more compelling as widespread educational reform efforts with scant attention to scholarship gain momentum across higher education institutions around the world. We argue here that SoCP should be central to program-level and institutional educational reforms on university campuses. We have attempted to provide a theoretical framework for SoCP, as well as practical examples for its strategic use and support (e.g., greater visibility of campus-wide curriculum renewal initiatives, educational leadership implications, increased scholarship opportunities, and strategic support mechanisms) drawn from our experiences in Canada and collaborations with colleagues around the world. While there are still many challenges and areas for improvement, an institutional commitment to SoCP can be the basis for strategic and systematic approaches to improve the quality of undergraduate and graduate education.

\section{ACKNOWLEDGEMENTS}

The authors would like to express their sincere thanks to UBC curriculum leaders and to colleagues from universities around the world who have provided key insights for this paper.

Harry Hubball is a Canadian National Teaching Fellow and the Academic Program Director for the UBC Faculty SoTL Leadership Program. 
Marion Pearson is a Senior Instructor and the Director of the Entry-to-Practice Program in the Faculty of Pharmaceutical Sciences, and a doctoral candidate in curriculum studies in the Faculty of Education at the University of British Columbia.

Anthony Clarke is a Professor in the UBC Department of Curriculum and Pedagogy and a Canadian National Teaching Fellow.

\section{NOTE}

1. The term "curriculum" has various meanings in different contexts. It is represented in various literatures and from multiple perspectives. For the purpose of this discussion, curriculum in higher education refers to an overall program of study (e.g., Bachelors, Doctoral, Postgraduate Certificate) with carefully designed, flexible, coherent, and integrated learning experiences (e.g., core courses, problem-based learning modules, field experiences, and capstone research projects) in order to develop students' knowledge, skills, and abilities. The term "course" refers to a typical 3-hour per week, 13-week unit within an overall academic program.

\section{REFERENCES}

Ambrose, S. A., Bridges, M. W., DiPietro, M., Lovett, M. C., Norman, M. K., \& Mayer, R. E. (2010). How learning works: Seven research-based principles for smart teaching. San Francisco: Jossey-Bass.

Arai, K., Cech, T., Chameau, J.-L., Horn, P., Mattaj, I., Potocnik, J., \& Wiley, J. (2007). The future of research universities. Is the model of research-intensive universities still valid at the beginning of the twenty-first century? European Molecular Biology Organization (EMBO) Reports, 8(9), 804-810. Retrieved August 31, 2010, from http://www.ncbi.nlm.nih.gov /pmc/articles/PMC1973958/

Bass, R. (2012). Disrupting ourselves: The problem of learning in higher education. EDUCAUSE Review, 47(2), Article 3. Retrieved July 23, 2012, from http://www.educause.edu/ero /article/disrupting-ourselves-problem-learning-higher-education

Bates, A. W., \& Sangrà, A. (2011) Managing technology in higher education: Strategies for transforming teaching and learning. San Francisco: Jossey-Bass.

Baxter Magolda, M. B. (1999). Creating contexts for learning and self-authorship: Constructivedevelopmental pedagogy. Nashville, TN: Vanderbilt University Press.

Beaudoin, B. B. (2012). Creating community: From individual reflection to SoTL transformation. International Journal for the Scholarship of Teaching and Learning, 6(1), Article 16. Retrieved January 31, 2012, from http://academics.georgiasouthern.edu/ijsotl/v6n1.html

Boyer, E. L. (1990). Scholarship reconsidered: Priorities of the professoriate. Princeton, NJ: Carnegie Foundation for the Advancement of Teaching.

Bresciani, M. J. (2006). Outcomes-based academic and co-curricular program review. Sterling, VA: Stylus Publishing, LLC.

Bryk A. S., Gomez L. M., \& Grunow, A. (2011). Getting ideas into action: Building networked improvement communities in education. Retrieved July 23, 2012, from http://www .carnegiefoundation.org/sites/default/files/bryk-gomez_building-nics-education.pdf 
Campbell, D. T., \& Stanley, J. C. (1963). Experimental and quasi-experimental designs for research. Boston, MA: Houghton Mifflin.

Chickering, A. W., \& Gamson, Z. F. (1987). Seven principles for good practice in undergraduate education. AAHE Bulletin, 39(7), 3-7.

Chism, N. V. (2007). Peer review of teaching: A sourcebook ( $2^{\text {nd }}$ ed.). Bolton, MA: Anker Publications.

Christensen Hughes, J. (2007). Supporting curriculum assessment and development: Implications for the faculty role and institutional support. New Directions for Teaching and Learning, 112, 107-110.

Clark, D. J., \& Saulnier, B. M. (2010). Broadening the role of the teaching and learning center: From transforming faculty to transforming institutions. Journal on Centers for Teaching and Learning, 2, Article 7, retrieved June 29, 2012, from http://celt.muohio.edu/jctl/issue.php?v=2\&n=0

Cochran-Smith, M., \& Lytle, S. (2004). Practitioner inquiry, knowledge, and university culture. In J. J. Loughran, M. L. Hamilton, V. K. LaBoskey, \& T. Russell (Eds.), International handbook of self-study of teaching and teacher education practices (pp. 601-650). Dordrecht, The Netherlands: Kluwer Academic Publishers.

Collins, S., \& Clarke, A. (2008). Activity frames and complexity thinking: Honoring both public and personal agendas in an emergent curriculum. Teaching and Teacher Education, 24(4), 1003-1014.

Conrad, C. F., \& Pratt, A. M. (1983). Making decisions about the curriculum: From metaphor to model. Journal of Higher Education, 54(1), 16-30.

Cousin, G. (2009). Strategies for researching learning in higher education: An introduction to contemporary methods and approaches. London: Routledge.

Davis, B., \& Sumara, D. (2006). Complexity and education: Inquiries into learning, teaching, and research. Mahwah, NJ: Lawrence Erlbaum Associates.

Diamond, R. M. (1998). Designing and assessing courses and curricula: A practical guide. San Francisco: Jossey-Bass.

Dressel, P. L. (1968). College and university curriculum. Berkeley, CA: McCutchan.

Elen, J., Lindblom-Ylänne, S., \& Clement, M. (2007). Faculty development in research-intensive universities: The role of academics' conceptions on the relationship between research and teaching. International Journal for Academic Development, 12(2), 123-139.

Friedman, V. J. (2008). Action science: Creating communities of inquiry in communities of practice. In P. Reason \& H. Bradbury (Eds.), Handbook of action research: The concise paperback edition (pp. 131-143). Thousand Oaks, CA: SAGE Publications.

Fullan, M. G. (2001). The new meaning of educational change ( $3^{\text {rd }}$ ed.). New York: Teachers College.

Glassick, C. E., Huber, M. T., \& Maeroff, G. I. (1997). Scholarship assessed: Evaluation of the professoriate. San Francisco: Jossey-Bass.

Green, L. W. (1986). The theory of participation: A qualitative analysis of its expression in national and international health policies. Advances in Health Education and Research, $1,211-236$. 
Green, L. W. (2008). Making research relevant: If it is an evidence-based practice, where's the practice-based evidence? Family Practice, 25(Suppl. 1), 20-24.

Green, L. W. (2012). Dissemination of evidence-based practice versus practice-based evidence. University of California, San Francisco School of Dentistry, Public Health Dentistry Online Seminar and National Webinar, January, 2012.

Green, L. W., and Kreuter, M. W. (1991). Health promotion planning: An educational and environmental approach. Palo Alto, CA: Mayfield Publishers.

Hansman, C. A. (2001). Context-based adult learning. New Directions for Adult and Continuing Education, 89, 43-52.

Haworth, J. G., \& Conrad, C. F. (1997). Emblems of quality in higher education: Developing and sustaining high-quality programs. Boston: Allyn and Bacon.

Holt, D., Palmer, S., \& Challis, D. (2011). Changing perspectives: Teaching and learning centres' strategic contributions to academic development in Australian higher education. International Journal for Academic Development, 16(1), 5-17.

Hubball, H., \& Burt, H. (2004). An integrated approach to developing and implementing learning-centred curricula. International Journal for Academic Development, 9(1), 51-65.

Hubball, H., \& Burt, H. (2007). Learning outcomes and program-level evaluation in a fouryear undergraduate pharmacy curriculum. American Journal of Pharmaceutical Education, 71(5), 1-8.

Hubball, H., \& Clarke, A. (2010). Diverse methodological approaches and considerations for SoTL in higher education. Canadian Journal for the Scholarship of Teaching and Learning, 1(1), Article 2. Retrieved July 23, 2012, from http://ir.lib.uwo.ca/cjsotl_rcacea/vol1/iss1/2/

Hubball, H., Clarke, A., \& Poole, G. (2010). Ten-year reflections on mentoring SoTL research in a research-intensive university. International Journal for Academic Development, 15(2), 117-129.

Hubball, H., \& Edwards-Henry, A.-M. (2011). International collaboration to align institutional teaching development, learning-centred curricula, and the scholarship of curriculum and pedagogy in higher education. The Caribbean Teaching Scholar, 1(1), 35-47.

Hubball, H. T., \& Gold, N. (2007). The scholarship of curriculum practice and undergraduate program reform: Integrating theory into practice. New Directions for Teaching and Learning, 112, 5-14.

Hubball, H., Gold, N., Mighty, J., \& Britnell, J. (2007). Supporting the implementation of externally generated learning outcomes and learning-centered curriculum development: An integrated framework. New Directions for Teaching and Learning, 112, 93-105.

Hubball, H., Lamberson, M., \& Kindler, A. (2012). Strategic restructuring of a centre for teaching and learning in a research-intensive university: Institutional engagement in scholarly approaches to curriculum renewal and pedagogical practices. International Journal of University Teaching and Faculty Development, 3(2), Article 2. Retrieved October 15, 2012, from https://www.novapublishers.com/catalog/product_info.php?products_id=38085

Hubball, H., \& Pearson, M. L. (2009). Curriculum leadership portfolios: Enhancing scholarly approaches to undergraduate program reform. Transformative Dialogues: Teaching and Learning Journal, 3(2), 1-16. 
Hubball, H., \& Pearson, M. L. (2010). Grappling with the complexity of undergraduate degree program reform: Critical barriers and emergent strategies. Transformative Dialogues: Teaching and Learning Journal, 3(3), 1-17.

Hubball, H., \& Pearson, M. L. (2011). Scholarly approaches to curriculum evaluation: Critical contributions for undergraduate degree program reform in a Canadian context. In M. Saunders, P. Trowler, \& V. Bamber (Eds.), Reconceptualising evaluation in higher education: The practice turn. Maidenhead, UK: Open University Press/SRHE.

Hutchings, P. (2007). Theory: The elephant in the scholarship of teaching and learning room. International Journal for the Scholarship of Teaching and Learning, 1(1), Article 1. Retrieved October 15, 2012, from http://academics.georgiasouthern.edu/ijsotl/v1n1/essays/hutchings /IJ_Hutchings.pdf

Hutchings, P., Huber, M. T., \& Ciccone, A. (2011). The scholarship of teaching and learning reconsidered: Institutional integration and impact. San Francisco: Jossey-Bass

Kanuka, H. (2011). Keeping the scholarship in the scholarship of teaching and learning. International Journal for the Scholarship of Teaching and Learning, 5(1). Retrieved December 15, 2010, from http://www.georgiasouthern.edu/ijsotl

Kurtz, G., \& Sponder, B. (2010). SoTL in online education: Strategies and practices for using new media for teaching and learning online. International Journal for the Scholarship of Teaching and Learning, 4(1), Article 1. Retrieved July 23, 2012, from http://academics .georgiasouthern.edu/ijsotl/v4n1/invited_essays/PDFs/Invited_Essay_KurtzSponder.pdf

LaBoskey, V. K. (2004). The methodology of self-study and its theoretical underpinnings. In J. J. Loughran, M. L. Hamilton, V. K. LaBoskey, \& T. Russell (Eds.), International handbook of self-study of teaching and teacher education practices (pp. 817-869). Dordrecht, The Netherlands: Kluwer Academic Publishers.

Lave, J., \& Wenger, E. (1991). Situated learning: Legitimate peripheral participation. New York: Cambridge University Press.

Marshall, S. J., Orrell, J., Cameron, A., Bosanquet, A., \& Thomas, S. (2011). Leading and managing learning and teaching in higher education. Higher Education Research \& Development, 30(2), 87-103.

McKinney, K. (2012). Increasing the impact of SoTL: Two sometimes neglected opportunities, International Journal for the Scholarship of Teaching and Learning, 6(1). Retrieved January 30, 2012, from http://academics.georgiasouthern.edu/ijsotl/v6n1.html

National Survey of Student Engagement. (2005). Exploring different dimensions of student engagement: 2005 Annual survey results. Retrieved August 30, 2012, from http://nsse.iub .edu/pdf/NSSE2005_annual_report.pdf

Ottoson, J. M., and Green, L. W. (1987). Reconciling concept and context: Theory of implementation. Advances in Health Education and Promotion, 2, 353-382.

Pearson, M. L., \& Hubball, H. (in press). Scholarly approaches to curricular integration: Theorypractice implications for pharmacy programs. American Journal of Pharmaceutical Education.

Pinar, W. F. (2012). What is curriculum theory? ( $2^{\text {nd }}$ ed.). New York: Routledge.

Richlin, L., \& Cox, M. D. (2004). Developing scholarly teaching and the scholarship of teach- 
ing and learning through faculty learning communities. In M. D. Cox \& L. Richlin (Eds.), Building faculty learning communities, New Directions for Teaching and Learning, 97 (pp. 127-136). San Francisco: Jossey-Bass.

Saunders, M., Trowler, P., \& Bamber, V. (Eds.) (2011). Reconceptualising evaluation in higher education: The practice turn. Maidenhead, UK: Open University Press Publishers/SRHE.

Scriven, M. (1967). The methodology of evaluation. In R. W. Tyler, R. M. Gagné, and M. Scriven (Eds.), Perspectives of curriculum evaluation (pp. 39-83). Chicago, IL: Rand McNally Publishers.

Senge, P. M. \& Scharmer, C. O. (2008). Community action research: Learning as a community of practitioners, consultants and researchers. In P. Reason \& H. Bradbury (Eds.), Handbook of action research: The concise paperback edition (pp. 195-206). Thousand Oaks, CA: SAGE Publications.

Shulman, L. S. (1986). Those who understand: Knowledge growth in teaching. Educational Researcher, 15(2), 4-14.

Shulman, L. S. (2005). Signature pedagogies in the professions. Daedalus, 134(3), 52-59.

Stake, R. E. (1975). An interview with Robert Stake on responsive evaluation. In R. E. Stake (Ed.), Evaluating the arts in education: A responsive approach (pp. 33-58). Columbus, $\mathrm{OH}$ : Merrill Publishers.

Svinicki, M. D. (2012). Who is entitled to do SoTL? International Journal for the Scholarship of Teaching and Learning, 6(2). Article 1. Retrieved June 29, 2012, from http://academics .georgiasouthern.edu/ijsotl/v6n2/invited_essays/PDFs/IE_Svinicki.pdf

Taba, H. (1962). Curriculum development: Theory and practice. New York: Harcourt, Brace, and World.

Tierney, W. G. (1989). Cultural politics and the curriculum in postsecondary education. Journal of Education, 171(3), 72-88.

Tyler, R. W. (1949). Basic principles of curriculum and instruction. Chicago: University of Chicago Press.

University of British Columbia (2011). The Centre for Teaching, Learning and Technology: Universitas 21 Teaching and Learning Network Meeting 2011. Retrieved August 18. 2012, from http://ctlt.ubc.ca/about-isotl/resources-archives/universitas-21-teaching-and-learning -network-meeting-2011/

Wagner, E., \& Ice, P. (2012). Data changes everything: Delivering on the promise of learning analytics in higher education. Educause Review, 47(4). Retrieved August 15, 2012, from http://www.educause.edu/ero/article/data-changes-everything-delivering-promise -learning-analytics-higher-education

Weiss, C. H. (1973). Where politics and evaluation meet. Evaluation, 1(3), 37-45.

Westerheijden, D. F., Stensaker, B., \& Rosa, M. J. (Eds.). (2007). Quality assurance in higher education: Trends in regulation, translation and transformation. Dordrecht, The Netherlands: Springer.

Wenger, E., McDermott, R. A., \& Snyder, W. M. (2002). Cultivating communities of practice: A guide to managing knowledge. Boston, MA: Harvard Business School Press. 
Wieman, C., Perkins, K., \& Gilbert, S. (2010). Transforming science education at large research universities: A case study in progress. Change, 42(2), 7-14. Retrieved June 29, 2012, from http://www.changemag.org/Archives/Back\%20lssues/March-April\%202010/transforming -science-full.html

Wong, T. J., \& Hubball, H. (2011). Examination of curriculum reform in a four-year program of pediatric dentistry. Transformative Dialogues: Teaching and Learning Journal. 5(1). Retrieved August 5, 2012, from http://kwantlen.ca/TD/TD.5.1/ 